\title{
Towards the implementation of an integrated approach to fisheries resources management in Ifremer, France
}

\author{
Serge M. Garcia ${ }^{1}$ and Patrick Prouzet ${ }^{2, \mathrm{a}}$ \\ 1 Former Director, FAO Fisheries Management Division (retired) \\ 2 Ifremer, DPCP, 1 allée du Parc Montaury, 64600 Anglet, France
}

\begin{abstract}
Implementing the Ecosystem Approach to Fisheries is a demanding exercise even though a more or less sophisticated approach might be adopted depending on the fishery or problem concerned and on the capacity available to deal with it. In France, DEMOSTEM, a programme of Ifremer was established to try to practically apply the EAF principles across the high diversity of situations existing in the country. The article summarizes very briefly the lessons learned through this programme implementation and some of the key findings and outcomes. In conclusion, it offers some perspectives on the whole process.
\end{abstract}

\section{Introduction}

During the last decade, the co-evolution of fishery science and governance, at the interface between the aquatic systems and their users, has been ongoing at a faster pace. On the one hand, societal environmental concerns concerning contamination, habitat degradation and climate change are growing, calling for more comprehensive, anticipatory and precautionary action and hence advice. On the other hand, computing and observation capacity have developed very significantly, allowing the development of more comprehensive and sophisticated simulation models in support of a more systemic approach to resources assessment, advice and management. At the front edge of this trend is the Ecosystem Approach to Fisheries (EAF).

EAF has been adopted by FAO member countries in 2001 in Reykjavik and formally recognized by the World Summit on Sustainable Development (WSSD) in 2002 when, in its Plan of Implementation (POI) "it encouraged the implementation of the ecosystem approach by $2010(\$ 30 d)$; to maintain or restore stocks to the level that can produce MSY by 2015 (\$ 31a); and to develop and facilitate the elimination of destructive fishing practices, the establishment of marine protected areas... including representative networks by $2012, \ldots$ the protection of nursery grounds and periods, proper coastal land use and watershed planning and the integration of marine and coastal areas management... (\$31c)."

Since 2002, these WSSD generous commitments and specific targets, and the hopeful societal expectations it has

\footnotetext{
${ }^{\text {a }}$ In charge of the transversal coordination on Systemic Approach at Ifremer, Partrick. Prouzet@ifremer . fr
}

generated, are testing the available political will and capacity of governments. States are facing simultaneously a huge environmental bill -a small part of which relates to fisheries, the rising needs of a growing world population, a shortage of food and livelihood in many countries, in a context of deep economic crisis. Under these conditions, and considering the speed of past improvements, nobody can realistically expect that, by 2015, EAF will have been generally implemented and world stock rebuilt to agreed international norms. However, there will probably be inter alia: (i) a higher level of consciousness in governments; (ii) better adapted governance systems; (iii) greater willingness of the industry to collaborate; (iv) more accessible scientific and (hopefully) grey literature on EAF; (v) some specialised multidisciplinary databases and open source software libraries; (vi) an array of tested tools (including simulation models); (vii) approaches and repositories of good practices adapted to particular situations and reflecting a large body of experience to be constructively used after 2015 . It should be a minimum duty of the States that have adopted EAF and the WSSD plan of implementation to contribute as much as possible to that outcome.

This paper looks briefly at the international and national context within which the EAF must be implemented before looking at some specific projects implemented by Ifremer to facilitate such implementation. The conclusion offers some elements of perspective for the future implementation steps.

\section{EAF implementation context}

The task of the States in trying to fulfil their commitments should be facilitated to some extent by the fact that the 
provisions of the 1982 United Nations Law of the Sea Convention (LOSC) and the 1992 Convention on biological diversity (CBD) have been reflected in the 1995 FAO Code of conduct for responsible fisheries (the Code), and its technical guidelines ${ }^{1}$. In addition, the measures envisaged by WSSD are part of the Ecosystem Approach to Fisheries (EAF) and reflected in the specific technical guidelines (e.g. FAO 2003, 2008). Therefore, the implementation of EAF by coastal and fishing nations is the integrated way to fulfil many of their obligations under the LOSC and the CBD in the fishery sector.

The European 2000 Water Framework Directive ${ }^{2}$ and the Maritime Policy (2000/60/EC, 23 October 2000) will significantly influence space-based management in coastal areas. These areas, strongly impacted by all human coastal and inland activities, are the main fishing grounds of the small- to medium-scale European fleets the socio-economic importance of which is largely underestimated.

In France, the concern for sustainability and the related commitments for a more sustainable use of the marine environment have been integrated in the 2009 Blue Book Commitments of the Oceans Round Table (Grenelle de la Mer ${ }^{3}$ ) and Ifremer as well as other competent French institutions are committed to contribute. The document proposes the elements for a French integrated maritime policy which foresees inter alia:

- Protecting and developing marine biodiversity, e.g. through: (i) designation of networks of marine protected areas (including in the high seas) by 2012; (ii) creation of marine reserves and sanctuaries and the improvement of existing ones; (iii) use of MPAs in fisheries management; (iv) protection/restoration of threatened marine species including marine mammals; (v) protection of critical and sensitive marine habitats including coral reefs, mangrove swamps, deep-sea corals, hot vents; (vi) reduction of land-based sources of pollution; (vii) integrated management of the coastline; (viii) promotion of eco-friendly agriculture in coastal areas; (ix) raising education and awareness raising

- Testing a participative Ecosystem Approach to Fisheries based on long-term ecosystemic management plans aiming explicitly at environmental, social and economic objectives. The approach is multi-pronged and will include inter alia: (i) fostering the development of more eco-friendly fishing technology (e.g. to reduce incidental catches and discards and reducing wastes); (ii) provision of incentives for innovation, fight against pollution, etc.); (iii) integration of ecologically sustainable aquaculture; (iv) development of ecolabels; (v) knowledge-building, particularly about and understand marine ecosystems, changes in them and their interrelation with land environments or coastal wetlands; (vi) establishment of reference conditions; (vii) reinforcement of the role of scientific advice;

- Improving the development policy and management frameworks of fisheries, through e.g.; (i) better integration of

\footnotetext{
${ }^{1}$ See http://www.fao.org/fishery/ccrf/publications/guidelines/en

2 The Directive 2000/60/EC of the European Parliament and of the Council establishing a framework for the Community action in the field of water policy i.e. the EU Water Framework Directive (WFD) was finally adopted on 23 October 2000.

${ }^{3}$ http://www.legrenelle-mer.gouv.fr/spip.php?rubrique61
}

the fishing activities into the coastal economy; (ii) fishermen diversification, facilitating their exit from the sector when relevant (including toward eco-tourism) and/or their contribution to ecosystem monitoring; (iii) improved supervision and management of recreational fishing; (iv) modernization of fishing organizations; (v) reform of the Common Fisheries Policy (CFP) towards more decentralized implementation of centrally decided plans and measures; (vi) more decisive fight against Illegal, Unreported and Unregulated (IUU) fishing; (vii) improved monitoring, control and surveillance (MCS) of the fisheries and the marine environment.

The comprehensive statement contained in the Blue Book Commitments of the Oceans Round Table is not yet a formal integrated marine policy but it indicates clearly the trend and, implicitly and explicitly, it puts marine science (and particularly fishery science) in front of the huge challenge to supply in due course, the high quality knowledge and decision-support that will be required if these commitments are to materialize.

However, the effective implementation of EAF and the shift of the expansion of the research object from the target population to its ecosystem is a major challenge. It represents an extension of the scope, objectives, constraints, and measures traditionally considered under conventional fisheries management. It also implies a significant increase in the amount of information needed on, inter alia: (i) more ecosystem components and their interconnections within the exploited ecosystem; (ii) better understanding of the goods and services produced and their values; (iii) more adapted governance structures and processes; (iv) better ways to account for uncertainty in decision-making and ensure effective participation; and (v) more economic ways to obtain and process the information needed. It tends to be "forgotten" that a full implementation of EAF requires also an alliance between natural and social sciences well beyond bio-economic modelling (see for instance Garcia and Charles 2007; Garcia 2008). It is also important to incorporate validated traditional knowledge into the processes of assessment, identification of options and elaboration of advice and, more generally, to develop active formal participation of the fishing communities concerned. Much more progress is needed in that direction and the EU Regional Advisory Councils are a useful step in that direction. Indeed the adoption of EAF requires the recognition that the fishery system is a complex social and ecological system, that can never be completely understood and hence predicted and that may have emergent properties leading to totally unexpected events.

The experience gained in integrated coastal area management (ICAM) and other "integrated management" (e.g. of watersheds) in the preceding 3 decades as well as in the more recent history of EAF implementation itself, represent a body of accumulated experience that can usefully be used (e.g. Bianchi and Skjoldal 2008).

What is often apparently not clearly perceived by those expecting more immediate implementation of EAF is the profound mutation that EAF requires from governance and research systems. The first needs to be upgraded substantially in order to face the new uncertainties and opportunities arising from the approach (Garcia 2009). The rapid adaptation needed 
in the management-support research is often underestimated. Warnings have been given about the larger uncertainties arising from the complexification of the system that have now to be explicitly dealt with (Garcia et al. 2003; Rice 2005; Garcia and Charles 2008). At the same time, these have been softened in order not to scare away the available good will, by stressing that low-complexity EAF was possible, using a precautionary, risk-based, adaptive implementation framework (Fletcher et al. 2002).

Nonetheless, in developed countries, the actors are used to receive fairly complex scientific support to decision-making, and the scientists are still tempted to look for a comprehensive understanding of the ecosystem in order to venture into any type of prediction. The industry has grown into a system providing "predictions" of the future state of the stock. It expects something similar under EAF. The details of the needed "mutations" in the information systems and scientific capacity have not really been described.

Ifremer is the large and complex public organization involved in all aspects of exploration and exploitation of the oceans by France. The institute has the mandate to conduct research and advice on fisheries management. Following the adoption of EAF, its four centres located all around France have started to change and adapt, to the new requirements, along the main priorities of the institute regarding its fisheryrelated programme:

- Long-term production and use of the data needed to understand the fishery system;

- Undertake analyses and foster the integration of a large range of indicators;

- Foresee the changes in fishery governance;

- Characterize the impacts of fishing and other human activities;

- Understand the influence of climatic forcing on populations and ecosystems dynamics;

- Maximise wealth though value addition to catch.

For Ifremer (as of any other fishery research institute in the European Union) the transition towards EAF is complicated by the fact that the responsibility for managing fisheries has been devolved to the European Commission which expresses, therefore, the social demand. That demand is addressed to the International Council for the Exploration of the Sea (ICES). There is therefore a partial "disconnect" in the French fishery research supply-demand process (as in any other European member country) between what might be the local requirements (e.g. within the French 12 miles zone) and those in the EU overall exclusive economic zone. In the marine/fishery science arena, this difficulty is mitigated by the setting up of numerous integrated, multi-country EU-funded research projects leading to syntheses at regional or European level on coastal fisheries, their resources, habitats and management. These projects are generally implemented by a network of stakeholders cooperating in a multi-partner ecosystemic approach. The $\mathrm{CHARM}^{4}$ and INDICANG ${ }^{5}$ projects are good examples.

\footnotetext{
${ }^{4}$ Eastern Channel habitat atlas for marine resource management.

5 Indicateurs d'abondance et de colonisation de l'anguille européenne dans la partie centrale de son aire de répartition.
}

Two special Programmes were established in France, in 2004, to foster and coordinate that change. SIDEPECHE ${ }^{6}$ dealt primarily with priorities 1 and 2 with a practical application focus, particularly on management advice, fishery biology and economy. It focused on automated data harvesting, data and information management, and decision-support analyses. DEMOSTEM $^{7}$ dealt essentially with the other four focusing on knowledge-building with a more forward looking concern. It focused on: (i) resilience at individual, population and ecosystem level; (ii) resilience of the sector in front of its ecological and economic challenges, through harvest rationalization, impact reduction, and post-harvest optimization. The results were presented to the Symposium, Boulogne sur mer, France, 5-7 November 2008, at which 39 papers and 46 posters were submitted (Prouzet et al. 2008, listed in Annex). The present issue contains a selection of papers across the range submitted. The contribution of the DEMOSTEM programme towards EAF is briefly described below. During the 2004-2008 period, 175 scientific papers and 334 communications had been produced in the framework of 127 research projects developed by the scientists and engineers under the DEMOSTEM program.

\section{DEMOSTEM objectives and main outcomes}

\subsection{Objectives}

DEMOSTEM intended to foster an integrated ecosystem approach to fishery management (Prouzet et al. 2008), broadening the analyses to cover also the range of uses affecting fishery resources. In line with the last four Ifremer priorities listed above, the programme defined the four priority axes of investigation (in no order of preference):

(1) Anticipate the fishery system governance changes, studying the future regulatory measures needed for the allocation of access to resources allocation and fishing capacity control;

(2) Characterize and limit impacts from fishing and other human stresses, (i) analysing the resilience of exploited ecosystem in a fluctuating and evolving environment; (ii) looking for means of mitigation or reduction of these impacts including technological innovations aiming at reducing the environmental impact of fishing and processing;

(3) Improve understanding of climatic forcing impact on individuals, populations, communities and ecosystems dynamics in order to improve foresight;

(4) Contribution to wealth maximization including bioeconomic sustainability of the fishery chain from harvesting to transformation and trade.

The main challenges faced related to: (i) effective consideration of multiple uses; (ii) involving and integrating multiple disciplines; (iii) experimenting with new types of regulations

\footnotetext{
${ }^{6}$ SIDEPECHE : "Systèmes d'information et techniques d'observation, économie et diagnostic de l'évolution des ressources et de leurs usages".

7 Démarche intégrée pour une gestion écosystémique des ressources halieutiques.
} 
(e.g. MPAs) and more participative approaches to management.

The results obtained throughout the DEMOSTEM program (as well as the relevant results obtained by SIDEPECHE) were presented at the symposium on the Ecosystem Approach for Fisheries held at Boulogne sur mer, 5-7 November 2008. Some of the scientific communications presented at that meeting have been peer-reviewed and are presented in this Special Issue. Many others have been published elsewhere. Altogether, these do not constitute and end point in a process but a transient report on an ongoing process. The symposium was used as peer review of the developing science and for a reflection on the future that will be reflected in the concluding section of this paper.

\subsection{Main outcomes}

A selection of the main outcomes of the programme are briefly reported below, following the four programme priorities mentioned above. The first priority has been addressed directly as well as indirectly in many programme activities related to priorities 2-4. The priorities 2 and 3 were dealt with together.

The considerations emerging from the programme could be regrouped in many different ways and many papers touch simultaneously on many aspects of EAF. As a consequence, what follows is not an exhaustive summary of the findings of the programme, as presented at the Symposium but our limited selection among the numerous relevant points that have emerged. More than specific results which would be too numerous to be given here, we focus on lessons and considerations of potential interest to the fishery community. In the following sections, we will refer to the symposium communications by referring to their number [in the full list provided in Annex].

\subsubsection{Improving the capacity to look ahead}

The process of progressive implementation of EAF requires a capacity to anticipate the potential consequences of the planned changes in fishery governance and management strategies, particularly regarding the regulation of access to resources and control of fishing capacity. It implies also a capacity to assess the present state of the fishery system and to predict (or at least to expect) natural environmental fluctuations, to understand their impact on the stocks and management performance, and to react adequately.

This capacity is built progressively across the whole system through a number of "small" actions which, together, achieve the main goal. The capacity to look into the future is increased, inter alia, though experimenting with measures, limiting the risk as far as practicable. More safely it can be improved by looking for experience in other countries ([47] Marchal et al., p. 483) identifying best practices. It is enhanced by the use of simulation models and the development of scenarios [44, 49, 55-58]. Finally, the perceptions of the fishers themselves should not be underestimated and mechanisms involving them directly in the decision-making process may also help improving the capacity of governance to look ahead.

\subsubsection{Effects of fishing and other natural or human-induced stresses}

One of the EAF pillars is the concern for the impact of fishing and other human activities on marine biodiversity and the ecosystem and to propose solutions to mitigate, reduce or eliminate that effect. The usual understanding among policymakers and educated public is that this requires much broader viewpoints than the conventional ones. However, large-scale and long-term changes can be related to effects occurring at a much lower scale and research should try to encompass all the relevant levels of analysis: the individual, the population, the assemblage/community and the ecosystem.

\section{Individual fish level}

The relation of the individual with its environment is central to the issue of prediction of future environmental change. At individual level, the analysis of calcified structures (otoliths) represent life cycle as well as environmental archives providing clues regarding the environmental of the animal and its response (in terms of growth). New slicing techniques such as the femtosecond laser [1], image processing [13] and microchemistry indicators such as the strontium/barium ratio [9] have improved our capacity to "read" these archives, providing clues regarding the life cycle and population parameters as well as migratory behaviour $[1,13]$. The use of genetic, biochemical and electronic tags such as archival tags ([4] Fromentin et al., p. 395) have opened significant opportunities to better understand the relation between the individual and its environment and the resulting behaviour. Applications to the European hake (Merluccius merluccius) improved our knowledge on the vertical and horizontal movements linked to tide amplitude or nychthemeral rhythm [2].

Understanding fish behaviour is important for fishing, assessment and protection. Aggregative behaviour of pelagic fishes around the fish aggregating devices (FAD), school behaviour of anchovy in the Bay of Biscay and Mediterranean Sea, and migratory behaviour of glass eels in estuary ([8] Prouzet et al., p. 525) as well as marine turtles [17] have been observed.

Reproduction is obviously central to sustainability. Key phenomena for resources resilience to both fishing and the environment are the maturation/reproduction process and recruitment determinism [5, 8, 10-12]. These have been a major concern and difficulty for conventional fishery science and remain so under EAF [5,6]. These phenomena are sensitive to environmental change and are likely to evolve under global warming. As climate changes, so will likely do the life parameters and having the capacity to detect such changes and to account for them is a major challenge. Modelling spawning processes [5] in relation to environment may be a way to foresee the possible changes in growth and maturation and hence on eggs and larval survival. It is now clearly established that the effect of selective fishing on the phenotypes can be significant and may affect life history parameters [7] such as growth, age at maturation.

Migration is, for many marine animals, a fundamental process of their life cycle. It involves strong interaction between 
individuals within the population. The migratory path may often be known but the determinism of migration remains often obscure. Measuring biomasses of migrating animals and modelling the migration process $[8,10]$ may be important for protection purposes but also for harvest regulations, particularly on migration fisheries harvesting larvae and immatures (e.g. shrimps, eels) $[16,19]$.

The impact of pollution on individual fish health [3] is an important element of the understanding and proof of the impact of pollution on fisheries resources.

\section{Fish population level}

At population level, the issue related to the synergetic effect of environmental oscillations and exploitation which has been central since the early 1930s, is aggravated and compounded by climate change. At that level, the important phenomena relate, inter alia: to stock structure $[15,26]$ and adequate population parameters for conventional assessment and modelling $[20,24]$ of the resources as well as their biological environment (e.g. populations of toxic algae [18]). Better efforts are needed to collect information on the environment, predator-prey relations, host-parasite relations [21], impact of discarding practices ([27] Pawlowsky and Lorance, p. 573). The need to "spatialize" all the analyses, calls for a more detailed definition of spatial distribution (of resources and fleets). Scientific surveys are essential but, because of their costs, habitat modelling is developing rapidly [23]. The increased capacity to tag large numbers of individual fish [4] and to get direct access to vessel operations data (e.g. through vessel monitoring system, VMS) or other on-board semi-automated stations [49] is improving rapidly our capacity to follow, model and predict the relations between the populations and the fleets. The movements between areas will relate to migrations and are essential to define protected "corridors" to connect MPA and to improve resilience [25].

Spatial distribution and habitats are important pieces of knowledge for EAF. Study of anchovy and sardine populations (Sardina pilchardus) in the Bay of Biscay and North Sea identified changes of habitats between the 1970s and the 2000s apparently related to environmental forcing [14]. Spawning grounds are special habitats which, under EAF, are given special relevance and need to be localised [22] and characterized for protection. Marine protected areas are habitats legally designated for special protection. Their use in fisheries management requires specific studies for their appropriate setting. Knowing habitat preferences of a species [23], its likely habitat extension can be modelled as well as its likely change in distribution under climate change.

The programme has contributed to increasing the Ifremer scientists' capacity to work on pelagic biodiversity ([29] Trenkel et al., p. 433) through: (i) the development of improved acoustic methods using autonomous underwater vehicles (AUVs); (ii) combined use of multi-frequency single-beam and multibeam echosounders; (iii) sophisticated onboard processing software and 3-D visualisation and (iv) automated or semi-automated classification of species or group of species. The technique was successfully applied in the Bay of Biscay, discovering new aggregation structures of pelagic fish and improving the estimates of biomasses.
The impact of fishing on non-target populations must be better studied. The research undertaken has improved our understanding of the impact of fishing on emblematic species (sharks, dolphins, turtles (26), birds). Progress has been made during the last decade but a lot remains to be done. For these species (as well as for target species) the harvesting and analysis of historical data [17] is really essential to understand better where we stand in comparison to the past. More generally, the problem of discards remains a sore point for fisheries. Action is obviously required to improve selectivity through gear modifications (see below) but in order to obtain the authorities and the fishers' support, analyses are needed to show the problems they create, in terms of ethics, ecosystem sustainability, accuracy of assessments [27].

The impact on life history traits of both fishing and natural oscillations requires better understanding to improve assessments and conservation. The study of the Bay of Biscay anchovy [5], clam [20], Northeast Arctic cod [7] indicated that a slow-down of the growth is linked to a decrease of the age of first maturation [6]. The results obtained on cod suggest that enforcing management rules favouring fishing practices that select intermediate sizes may be an option for mitigating fisheries induced evolution as age and size at maturation.

\section{Fish assemblages and ecosystem levels}

Maintenance of ecosystem "health" is an objective recurrently referred to, most often without a proper definition of what is intended by "health". During the programme, different approaches used in France to characterize the state of coastal ecosystems have been compared ([30] Brind' Amour and Lobry, p. 559). A methodological guide has been developed to define indicators for European eel habitat quality, recruitment level and colonization of freshwater environments (Adam et al. 2008). This methodology has been applied in a network of 13 catchments of the central part of the eel colonization area in Western Europe to evaluate the status of the eel resource and its environment in the framework of the INDICANG project (Prouzet 2004 [83]). Indicators measuring fishing impact on the status, functioning and dynamics of ecosystems have been defined [77]. Co-represented on a dashboard or traffic light table and submitted to managers and stake holders [76] they measure: i) the impact of fishing on benthic and demersal communities; ii) the impact of the urban and industrial development on the coastal areas, nurseries and fish resources ; and iii) the effect of fishing on the marine mammals.

The space-time dynamics of the fishery system must be addressed considering both the resource communities and the fisheries dynamics, usually at regional scale. The goal of research is to determine the conditions of viability taking into account the practical reality of fishing fleets and gears operations, the fish market, the governance and the perspective of climate change. This requires highly integrated studies that were undertaken in the CHALOUPE project in a comparative analysis of three regional ecosystems: the Bay of Biscay, a Moroccan upwelling, and the continental shelf of French Guyana. The results indicate that climate and fishing pressure had a significant combined effect on marine communities. The fisheries appear to be affected by the ecosystem dynamics, as expected, 
but they are mainly driven by changes in their economic environment [86].

Mapping habitats of populations and assemblages (overlaying them with forms of use) is one of the important supporting tasks of any EAF programme. Because of the number of species involved and the costs of scientific surveys, habitat modelling is an important tool. Based on known species or communities habitat preferences and environmental conditions (such as depth, temperature, salinity, bedstress and sediment) and using redundancy analysis, probability maps are elaborated that may delineate optimum habitats $[75,78]$ as well as marginal ones. Projected information on climate change may be translated in "future distribution" maps to see the impact of global change on the fish population structures and fish assemblages. In the framework of the INTERREG III A program of the European Union, a project called CHARM (Channel habitat atlas for marine resource management) developed in close collaboration with English scientists, an assessment of the status of benthic invertebrate fauna and key commercial fish species of the Eastern English Channel. The project's outputs are available to the public through an interactive Web atlas ([88] Martin et al., p. 499).

\section{Fishing and environment interactions}

It has always been considered essential, and found difficult, to elucidate the respective responsibility of fishing and of the environment on fish resources. There are two difficulties: (i) measuring effort properly (i.e. in a way really proportional to the impact); and (ii) separating the effect of effort from that of environment.

The first issue is a very conventional one, never fully satisfactorily resolved. The trends in fishing effort are analysed in terms of fishing power [42] and multivalency in order to precisely quantify the links among fishing capacity, fishing effort and fishing mortality. The use of the vessel monitoring systems (VMS) has allowed a better allocation of fishing effort not only in time, as usual, but also in space [49] with a high spatiotemporal resolution. This has allowed a more precise description of fishing activities (e.g. separating steaming and fishing time during a trip) and a better identification of different fishing boats categories (“métiers”) ([43] Daurès et al., p. 535).

\subsubsection{Optimizing wealth production and allocation}

Optimizing wealth distribution and, overall, wealth allocation (reaching equity) are two very high-stake challenges in the exploitation of natural resources use. The strategies required would normally seek to, inter alia:

- Adjusting effort or capacity to the resources productivity;

- Reduce unit operating costs (e.g. reducing fuel consumption);

- Increase the value of the catch through value addition and waste reduction.

The process of reduction of capacity implies a process of allocation of rights, during which the question of equity can be addressed.
If the issue is considered at societal level (and not only at sector level) than subsidies and externalities of the sector must be accounted for and reduced. The question of subsidies has not been addressed in the programme. The question of externalities (the cost of fishing to society) is only indirectly dealt with through the measures taken to reduce environmental impact.

\section{Adjusting effort or capacity to the resource productivity}

The necessary adjustments are determined in the fishery strategy and implemented in the fishery management. EAF being an extension of conventional management, serious efforts are still needed to improve conventional management under an EAF framework while testing complementary ecosystem-based regulatory devices such as marine protected areas (MPAs) [93].

In most fisheries, the priority to recover acceptable economic returns is on stock rebuilding and, naturally, ecosystem recovery. There is no shortage of prescriptions for "ill" fisheries but very little work still on viable recovery pathways [51] offering to managers a more complete panorama of the available options.

The assessment capacity available to identify and evaluate these pathways is variable, very high for some fisheries and very low in others. Regardless, the assessment of small coastal fisheries requires much more effort, particularly in economic and social assessments. Developing participatory research-and-management processes [86] will help to better understand fleet dynamics and fishing strategies [43], to optimize time and space allocation of effort [45], or to assess the potential effect of new management strategies such as the introduction of fishing rights ([53] Marchal et al., p. 463; [54] Hamon et al., p. 549). More studies of fishers' behaviour and motivations are needed $[55,56]$ to improve foresight. There is a need for joint analysis of environmental and economic drivers and this requires new approaches and models including behavioural models [44,49,55-58]. A focus is required on small coastal fisheries [43-46, 49, 50] which tend to be undervalued and neglected. Particular efforts are required for monitoring of fishing effort and automated procedures [42] have been demonstrated successfully with innovative on-board and remote sensed technology, when possible [49]. Media-drummed panaceas are unlikely to work everywhere in every circumstances and systematic costs-benefits analysis [52] including environmental and social costs of action (and of inaction) are necessary.

One of the headaches of EAF lies in technical interactions between fleets, e.g. when one fishery catches, as by-catch, a species tightly regulated in another fishery. Combining stocks dynamics and fleets dynamics ([47] Marchal et al., p. 483) examined the consequence of the use of economic disincentives (taxes) in New Zealand in addition to quota management in a complex of 4 fleets and 19 "métiers" exploiting both hoki and hake. The modelling framework developed could readily be applied to the management of the hake and Nephrops fisheries in the Bay of Biscay. 


\section{Reduction of fishing ecological impact}

While this section can be considered by ecologists as dealing with impact reduction, for macroeconomists it deals with ways and means to reduce the externalities imposed by fisheries through degradation of the human environment.

The impact of fishing operations on the environment may be reduced in three ways; (i) improving the gear selectivity $[66,73]$; (ii) increasing avoidance of the gear by the protected species; (iii) replacing the gear by a more environmentfriendly one; and (iv) reducing the physical impact of the gear (e.g. trawl doors) on the environment [61]. The first is obtained, for example, using square mesh netting in trawls cod ends [66] or introducing bycatch excluder devices [67]. The second can be implemented using devices (e.g. sonic pingers) to deflect non target species such as marine mammals, away from the gear $[63,72]$. The third is more radical. Under some circumstances, trawls may be replaced by pots, e.g. to catch Nephrops [59, 68] or fish [70]. Similarly, drift nets may be replaced by automated lines, e.g. to catch tunas [60]. The fourth [61] requires particular skills in gear development and engineering to analyse the impact of every element of the gear. Measuring that impact in the field, in a credible manner and accurate manner, is a challenge. The improvement may be in terms of fuel consumption (contribution to greenhouse gases) or reduced impact on the habitat and the bottom. Simulations may be used. In all cases, a key difficulty is that of convincing fishers to adopt the new gear. Very often, participative research with fishers' involvement may help gaining credibility and legitimacy.

\section{Waste management}

Waste in fisheries is both an environmental issue (oil consumption, pollution, discarding), an economic issue (loss of economic returns) and an ethical issue (resulting in loss of societal support).

Processing waste has been addressed by the French SEApro network (sustainable exploitation of aquatic products) which proposes new upgrading procedures for the whole biomass that reduce wastes. In order to improve use, these technologies must aim simultaneously at producing fish, fish meat, as well as fishmeal and fish oils as well as derivatives for cosmetic, nutrition and pharmacy sectors [71].

Reducing oil consumption implies reducing reliance on towed gear and efforts to replace towed gear by fixed or passive gear, mentioned above (e.g. $[59,60,67])$ can contribute to the end.

The issue of discarding is a thorny one and it has been partly addressed under "improved selectivity" but must also be addressed in terms of the fate of the non-desired bycatch. The 2007 EC Communication COM(2007)136 to the Council and the Parliament foresees a reduction and ban of discards, accompanied by measures imposing the landing of the entire catch and incentives to improve selectivity (changes in fishing areas and real-time closures). It is therefore urgent to progress rapidly towards more selective gears and practices.

\section{Perspectives and conclusion}

The sections below draw significantly from the debate and the conclusions of the round table organized at the end of the symposium. Grateful thanks to the participants and particularly to the panel of experts: Paul Nival, Phillippe Cury, Michael Sinclair, Jean Boncoeur and Pierre-Georges Dachicourt.

\subsection{Emerging thoughts}

The ecosystem approach to fisheries represents the opportunity to get out of the simplistic vision of an aquatic production system as an ecological system evolving under humaninduced perturbations versus a social system evolving under natural constraints. It deals with a fishery system, composed of a natural and a human subsystem, functioning in interaction. That system is seen differently (has multiple realities) when seen from various angles by different actors.

EAF requires a standard multicriteria decision-making system in a multi-use system that is spatially complex, only partially described and incompletely understood. The approach tend to be holistic overall, e.g. at national or regional level, in the long term. In its day-to-day problem-solving mode of operation, however, it integrates only as far as needed to resolve the problem. It deals with incomplete information through a risk-based approach, the methodology for which exist but the application of which to fisheries is new (Fletcher 2008). Obviously, the risk considered refer to the environment, the resource, the fishers community and society. It is important to know where the knowledge gaps are, what they might imply, and to take that uncertainty into account.

Contrary to the global trend of rapid conceptual and technological development, within which science is in a process of rapid specialization in micro-disciplines and schools, EAF calls for a more effective blending of disciplines, methods and forms of knowledge as well as new forms of governance. This simple observation opens, however a number of important considerations.

\section{Sophisticated versus simple EAF}

The DEMOSTEM and SIDEPECHE projects, in close synergy, have shown the range of scientific activities that need to be conducted in order to put EAF in place in the most effective way possible. Despite a broad range of collaborations and an intense programme of work, it is obvious that only the surface of EAF has been scratched. Much more work is needed in the areas already covered such as in bioecological modelling or indicators. Many times more work is needed in the areas of environmentally friendly technology development, economics (micro and macro level) and, above all, on the social parameters of the sector to develop a real multi-partner effort.

DEMOSTEM showed that in less than a decade, the scientific community (at least within the same institution) can stand up to the task with impressive results from a large collaboration with national, European and international scientific teams implementing 38 European and international research projects on different EAF-related topics (Prouzet et al. 2008). 


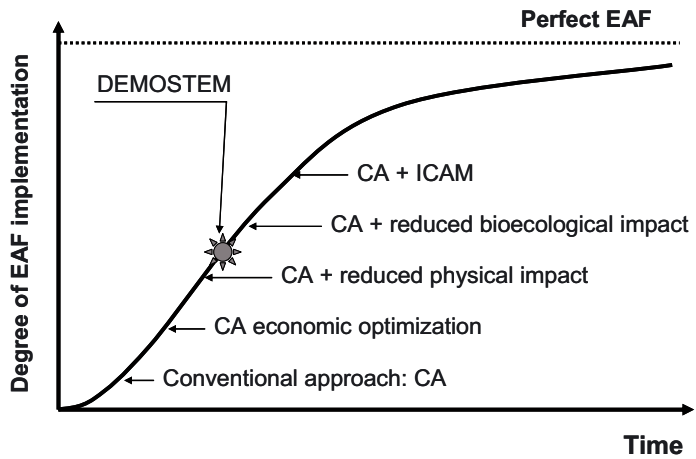

Fig. 1. Progressive development process of ecosystem approach to fisheries (EAF) and relative position of DEMOSTEM in that process. ICAM: integrated coastal area management.

But the change in data harvesting systems, data management systems, analytical methods, and modelling capacity take time. The adjustments of the institutions network, for a more cooperative and decentralized assessment-advice-decision system requires political decisions, budgets and decentralized capacitybuilding that, in times of economic crisis may not be easy to achieve. However, the rise of societal concern, the need to fight pollution and environment degradation, and to gain economic efficiency are all positive factors. The passage to a comprehensive EAF (in the sense of the FAO Guidelines) can only be progressive. DEMOSTEM is a first important step (Fig. 1).

Is this a path-dependent perception from within an institution that has the benefit of a long tradition and a significant budget and workforce in a rather well structured country? Some scientists working mainly in developing countries hold that a much simpler EAF must be possible, e.g. using a highly participative approach, traditional or local knowledge (validated if possible) and a risk assessment process, more or less quantitative depending on the data available (e.g. Fletcher et al. 2002; Fletcher 2008). Indeed, in many developing countries, FAO is developing and testing such a minimal approach (Cochrane et al 2007).

It is obvious that the less the information available, the more uncertainties around the decision to be made and the highest the risk of mistake. A precautionary approach is in order in all cases, but with less information at hand, and higher risks, more conservative positions must be taken, perhaps overconservative ones. Ideally, one should compare the cost of the foregone opportunities with the cost of the possible mistakes.

In any case, this is a non-issue as in developing countries and in developed ones the level of EAF applied will be dictated by the system "culture" 8 and the means available. The fact remains however, that even in a developed country, different fisheries have different values and may afford different degree of EAF sophistication. Small-scale fisheries, in Europe or Africa may indeed only be able to afford the simpler versions of EAF. There is no guaranty that the most expensive will be the best managed anyway.

\footnotetext{
${ }^{8}$ Systems using courts to resolve conflicts will require high level of proof. Those based on negotiation in participative mode may be more accommodating in case of "shared error".
}

During the Symposium, attention was drawn on the risk of making EAF more complicated than needed, getting away from simpler solutions more immediately applicable. He stressed the fact that the scientific community does not have yet the expertise in assessment and management of ecosystems and may be tempted to hide behind the need for more information to push the elaboration of solutions (accounting for incomplete information) to current problems such as excess capacity and habitat destruction. Recalling the precautionary approach (an integral part of the FAO EAF) the lack of scientific certainty cannot be an excuse for inaction when the risks are high. The challenge will therefore be, depending on the demand, to select the approach to use, within the range available and affordable.

The programme has demonstrated in particular the value of transdisciplinary work and the strong incentive that EAF represents to foster such cross-discipline collaboration. It has also shown the necessity to integrate the considerations across the whole fish production chain. Obviously, not all questions will require the mobilisation of all disciplines across the whole sector, but all questions need to be resolved keeping in mind the inter-connections in the complex social-ecological system of fisheries. This is of course not a "discovery" but DEMOSTEM has tested a possible way to implement the required change in the scientific institutional support (see Sect. 4.2).

Evaluating and distinguishing fishery impacts from all other human-induced impacts on the resources is an important priority for which fishery science, alone, is poorly prepared and for which strategic alliances will be needed, e.g. with ecotoxicologists, biochemists, terrestrial ecologists, fish physiologists, etc. Failing this, fisheries will remain, in the eye of society, the only culprit of aquatic resources degradation.

\section{Implications of action-oriented EAF}

It may be important to stress here that EAF is a field of integrated activities oriented towards management and more specifically sustainable use of aquatic ecosystems by fisheries. It is an applied field for research and the connection with management is essential. There cannot be EAF science without that orientation.

However, fishery science -in its broadest sense- exists in its own development system too, with its governance, rules and incentives. It should therefore organize itself in order to be ready to respond when new questions emerge. There is a need to organize research around case studies (scientific arenas) in which disciplines can collaborate, developing integrated processes of analysis and methods. Formally facing management questions, or simply aware of them, the scientific community need to translate them into scientific questions and collaborate to solve them, producing the peer-reviewed publications needed for its promotion. As in conventional assessment work, a difficulty that can be expected is that of being sufficiently available to resolve operational problems (providing expertise) while keeping enough time to elaborate acceptable scientific products. In addition, in the developing Mode 2 research philosophy (Nowotny et al. 2001), significant time must be kept aside to develop project proposals and hence raise funds.

The close association of science with EAF decisionmaking leads to expectations from the sector requiring a high 
degree of reactivity that conventional fishery science has been systematically criticised for not having. This long-standing problem result obviously from the differences in the dynamics of crises and of science. It can probably only be alleviated in part by developing, in science, a better foreseeing capacity, developing databases and methods that could then be rapidly mobilized in case of crises. This is, however, a substantial challenge in terms of human and financial resources.

In order to meet the sector and societal expectations in terms of reactivity and quality, the knowledge bases must be improved but, more importantly perhaps, the relationships between science and the sector need to be upgraded. This can be achieved by bringing the sector more forcefully into the assessment and advisory frameworks (Garcia 2008) developing more participatory data collection systems, assessment procedures, and advisory processes.

\subsection{What's next?}

A significant "paradigm shift" in fishery science is happening with the progressive implementation of EAF preparing the future for a more integrated approach to the use and management of marine ecosystems goods and services and the conservation of ecosystem resilience as a necessary condition for sustainable resource use. This EAF conceptual framework raises new questions for fisheries experts whilst at the same time broadening related fields of research. "Acknowledging the failure of fisheries governance and its roots causes leads to focusing on a better understanding of the fisheries dynamics in response ecological, economic and institutional changes in their contexts and on assessing their impacts in terms of collective (and not exclusively fishery-related) benefits. Studies progressively encompass interactions between fisheries uses and other uses of living marine resources, indicating the progressive adoption of the broader approach aimed at by the EAF" (Fromentin et al. 2007).

It could be stressed again that global warming is ongoing and that fisheries can only minimize the economic, social and ecological stress this change will produce, through an effective EAF. The collision between the global concern for the environment and the global change in governance practice (partnership, democracy, market driven) imply a strong change in the scope of the assessment, the type of customers, the type of output expected (advice, not only scientific papers) and the institutions connecting science to industry and both to decisionmaking.

It is difficult to generalize as to what needs to be done next to foster the implementation of EAF. The response will depend on the context, the nature of the social demand, the origin and the extent of the crises, the value of the fisheries, the competence available. Nonetheless, some general considerations could be made.

\section{Operational set-up: Arenas and workshops}

DEMOSTEM has shown that an effective organization of the work at such a high level complexity requires its structuration in arenas and workshops (Fig. 2):

- Arenas are either geographic or ecosystemic and in any case space-based concepts. They are the loci of partnership

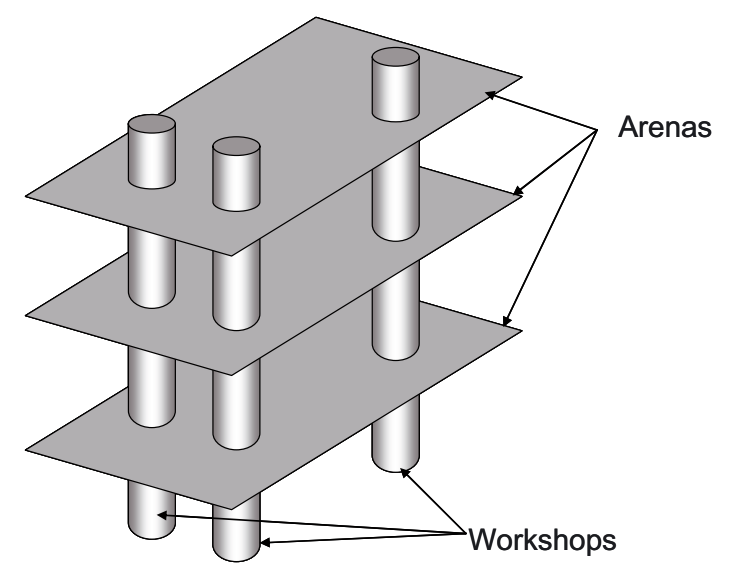

Fig. 2. Arenas and workshops.

application of a multidisciplinary process of action. Such process is problem-oriented or strategic and requires action-research. It is probably the device with which decision-makers are more familiar. It has the dimensions along which social demand will probably be expressed. The CHARM project [88], associated with the ARCManche initiative (http://www.arcmanche.com/) will constitute a good example of geographic arena within which it will be possible to develop a real scientific mediation process. An example of ecosystemic arena is given by the project for the restoration of the eel resources and its habitats in the central part of its distribution area (from the British Islands to the Iberian peninsula) and the project INDICANG [83] that have produced, in collaboration with the fishery and management stake-holders, a methodological guide to elaborate indicators for European eel habitat quality, recruitment level and colonization of freshwater environments.

- Workshops are transverse devices. They are thematic, methodological (ex.: comparative analyses), deal with tools development, information systems, conceptual development, cross arenas-strategies. They correspond more to the way science will organise its production and supply of knowledge. Their dimensions are more familiar to scientists and academics. Examples of these cross-cutting initiatives are given by: (i) the CHALOUPE project [86] including a comparative analysis of three regional ecosystems: the Bay of Biscay, a Moroccan upwelling, and the continental shelf of French Guyana: (ii) the joint synthesis on the use of genetic, biochemical and electronic tags to better understand the relation between the individual and its environment [4].

\section{Applying a really systemic approach}

It might be important to stress here that it is important to move towards a really "systemic" approach to fisheries research and management. EAF (or Ecosystem-Based Fishery Management and other very similar concepts) tend to be used as a flag, described and implemented by fishery biologists and ecologists, focusing therefore naturally on the natural part of the ecosystem, its components and its "health", leaving aside if not simply ignoring the socio-economic dimensions of the 
ecosystem of which humans are an integral part. EAF, as originally defined by FAO (Garcia et al. 2003; FAO 2003) is comprehensive, truly multi-disciplinary and integrated. Its full application requires a "systemic approach" as advocated more specifically by Garcia and Charles (2007) with a high level of integration between assessment, elaboration of advice and decision-making (Garcia 2008). This result cannot be achieved without the development of an appropriate institutional framework in which principles, the principles of EAF are mainstreamed and in which processes are designed for EAF, to achieve quality, integration, legitimacy, relevance, timeliness.

This set-up should be able to act in a pragmatic but effective way in a complex and changing ecological and socioeconomic environment. The key words are flexibility, reversibility, integration, production chain, knowledge sharing, transparency, clear allocation of mandates and responsibility.

The close association of stakeholders in the whole process, from assessment to planning and implementation is essential as well as the mobilisation, validation and use of traditional (informal) knowledge of the fishers.

\section{Fostering mapping and modelling}

EAF requires integration of information in an ecosystem space (often fuzzily bounded) that requires a cartographic vision of the information available. Developing a mapping capacity (e.g. in GIS) is therefore a must. Developing a capacity to produce maps through modelling is also a strong necessity considering the costs of observation. Finally, visualizing information in the forms of maps, in atlases, for example, is an excellent way of communicating the information to the users and to public at large. New open platforms are developing on the web, providing facilities for mapping (including Google Ocean) that can be put to use.

Modelling is another (and related) fundamental need in aquatic world and with human communities on which experimentation is at best difficult and at worst dangerous. Modelling, with all its caveats, is absolutely necessary to EAF. The range is vast, from simple mental models developed in participative mode, with fishers, to complex ecosystem simulation models used, e.g. to test management strategies. Modelling fishery management scenarios, e.g. for stock rebuilding, is important, integrating of course economic and social considerations. The key difficulties (as described in Garcia and Charles (2007) is to develop models integrating data from multiple disciplines, formal and informal, quantitative and qualitative. The establishment of open-source platforms on the web would greatly enhance the effectiveness of limited human resources available in the fisheries community.

\section{Developing communication}

EAF, de facto, pulls fishery science out of its very specialized area of fishery management where it has operated "quietly" for decades into a much broader and turbulent environmental arena in which it is in direct contact with a broader range of disciplines, stakeholders and even with the public at large. The concerned community must communicate much more and much more efficiently than in the past using the range of media that modern times offer, particularly through the web.

\section{Developing a web-based epistemic community EAF}

It is largely agreed that, as most part of the production of the marine ecosystem is located in the coastal area, the conservation of the marine resources and their habitats is strongly linked to the a sustainable use of the related goods and services in coastal, estuarine and freshwater environments. This implies that the broader setting required by EAF calls for the consideration of a much broader range of stakeholders and types uses in order to deal with the effects of the range of uses on the productivity of the marine ecosystem and on fisheries. That will require a true multidisciplinary scientific mediation and the incorporation of traditional knowledge for more integrated public policies.

The need to exchange information across disciplines, countries and ecosystems would be better and more rapidly satisfied if a true epistemic community could be developed. The scattered research potential available will come together naturally around formally established workshops and arenas (see above). At a broader level, however, the EAF implementation process (still scattered and not coordinated) would benefit greatly in terms of visibility, coherence and effectiveness from establishing a real epistemic community within which with common problems can be examined and resources and solutions could be shared. Using internet facilities, regional and global platforms could be developed or strengthened such as open-source modelling and methodological development platforms, common repositories of software, interactive mapping sites, knowledge bases, virtual working environments and other means to federate knowledge, cooperate and communicate. The climate change community has shown a good example of this.

Some integrated websites initiatives already exist of local or sub-regional scope such as the Ecoscope (http://www. ecoscopebc.ird.fr/) or Observatoire global du Saint-Laurent (http://ogsl.ca/fr.html), allowing to mix and exchange data, models, knowledge and know-how. More can be done for joint model development, inter alia following on and broadening the example of the $\mathrm{R}$ statistical modelling platform (http:// www.r-project.org/) and offspring projects like the FLR Library project (http://flr-project.org/) in fisheries and the automatic differentiation model builder (ADMB) platform (http:// admb-project.org/). The coalescence of existing scattered initiatives around one are more epistemic platforms, providing interactive exchange of information, case studies, best practices, grey literature (like policies, plans and projects), e-training, econferencing, dedicated media-corners etc. would greatly improve the development speed, coherence and effectiveness of such a community. There is certainly enough potential and enough demand in Europe to start with at that regional level.

\section{References}

Adam G., Feunteun E., Prouzet P., Rigaud C., 2008, L'anguille européenne- Indicateurs d'abondance et de colonisation. Editions QUAE, Collection Savoir faire.

Bianchi G., Skjoldal H.R., 2008, The ecosystem approach to fisheries. Rome, FAO \& CABI.

Cochrane K., Augustyn C.J., Bianchi G., de Barros P., Fairweather T., Iitembu J.,app D., Kanandjembo A., Kilongo K., Moroff N., Nel 
D., Roux J.-P., Shannon L.J., van Zyl B., Vaz Velho F., 2007, Results and conclusions of the project Ecosystem approaches to fisheries management in the Benguela Current large marine ecosystem. FAO Fish. Circ. 1026.

FAO, 2003, Fisheries management. 2.The ecosystem approach to fisheries. FAO Techn. Guidelines for Responsible Fisheries 4 (Suppl. 2).

FAO, 2008, Fisheries management. 2. The ecosystem approach to fisheries. 2.1 Best practices in ecosystem modelling for informing an ecosystem approach to fisheries. FAO Tech. Guidelines for Responsible Fisheries, 4 (Suppl. 2, Add.1) FAO, Rome.

Fletcher R., 2008, Implementing an ecosystem approach to fisheries management: lessons learned from applying a practical EAFM framework in Australia and the Pacific. In: Bianchi G., Skjoldal H.R. (Eds.) The ecosystem approach to fisheries. Rome, FAO \& CABI, pp. 112-124.

Fletcher R., Chesson J., Fisher M., Sainsbury K., Hundloe T., Smith T., Whitworth B., 2002, National ESD reporting framework for Australian fisheries: the "how to" guide for wild capture fisheries. Fisheries Research and Development Corporation, Canberra, Project 2000/145.

Fromentin J.-M., Planque B., Thébaud O., 2007, The ecosystem approach to fisheries: what are the research priorities? Rapp. DEMOSTEM - DPCP, Ifremer, Paris.

Garcia S., 2008, Fisheries assessment and decision-making: towards an integrated advisory process. In: Bianchi G., Skjoldal H.R.
(Eds.) The ecosystem approach to fisheries. Rome, FAO \& CABI, pp. 158-196.

Garcia S.M., 2009, Governance, science and society: the ecosystem approach to fisheries. In: Grafton Q., Hilborn R., Squires D., Tait M., Williams M. (Eds.). Handbook of Marine Fisheries Conservation and Management. Oxford University Press, pp. 87-98.

Garcia S.M., Zerbi A., Aliaume C., Do Chi T., Lasserre G., 2003, The ecosystem approach to fisheries. FAO Fish. Tech. Pap. 443.

Garcia S.M., Charles A.T., 2008, Fishery systems and linkages: implications for science and management. Oceans Coast. Manage. $51,505-427$.

Nowotny H., Scott P., Gibbons M., 2001, Re-thinking science. Knowledge and the public in an age of uncertainty. Cambridge, Polity Press [\& edn. Belin, Paris 2003].

Prouzet P., 2004, INDICANG : un projet européen pour synthétiser nos connaissances sur l'anguille et sur la qualité de ses habitats. Chron. Eur. Pays de la Loire 54, 50-51.

Prouzet P., Ernande B.,Carpentier A., Reynal L., Farrugio H., Lorance P., Bergé J.-P., Baron R., Nouhant S., 2008, Rapport de restitution du programme Démarche intégrée pour une gestion écosystémique des ressources halieutiques - DEMOSTEM. Rapp. DPCP - Ifremer.

Rice J., 2005, Implementation of the ecosystem approach to fisheries management: asynchronous co-evolution at the interface between science and policy. Mar. Ecol. Prog. Ser. 300, 241-296. 


\author{
Annex \\ Communications presented at the Symposium on the Systemic Approach to Fisheries \\ Boulogne-sur-mer, France, 5-7 November 2008 \\ Summaries can be viewed at http://wwz.ifremer.fr/asp/content/download/32302/268094/file/rapportcondense.pdf
}

\begin{abstract}
Theme 1. Combined effects of fishing and other humaninduced pressures as well as natural environmental oscillations on marine ecosystems: responses at individual, population and assemblage levels
\end{abstract}

Session 1.1. Individual processes and responses of organisms to their environment and exploitation.

Moderator: B. Ermande

[1] Fablet et al. Understanding otolith biomineralization: from physico chemical signatures to numerical modelling

[2] De Pontual et al. First archival tagging on European hake: what have we learnt?

[3] Aubry et al. withdrawn

[4] Fromentin et al. Importance and future of individual markers for the ecosystem approach to fisheries

[5] Struski et al. Potentiel de ponte de l'anchois du golfe de Gascogne : utilisation d'un modèle bioénergétique forcé par une série à long terme

[6] Martyet al. Influence de la croissance et de la mortalité individuelles sur l'évolution de l'âge et de la taille à maturation

[7] Ernande et al. Effects of different types of gear selectivity on harvest-induced life history evolution in Northeast Arctic cod

\section{Poster session 1.1}

[8] Prouzet et al. Analysis and visualization of the glass eel behavior (Anguilla anguilla) in the Adour estuary and estimate of its upstream migration speed

[9] Tabouret et al. Use of strontium and barium as markers of European eel (Anguilla anguilla) habitats in the Adour basin: tools for an ecosystemic approach

[10] Huret et al. Observing and modelling : the steps towards understanding the survival variability of early lifestages of anchovy in the Bay of Biscay

[11] Amilhat et al. European silver eel quality in two Mediterranean lagoons: Bages-Sigean and Canet-St-Nazaire (France) as an indicator of spawners potential

[12] Ernande et al. Estimating the onset of maturation and related energy allocation parameters from somatic growth

[13] Carbini et al. A review of image-based tools for automatic fish ageing from otolith features

Session 1.2. Interactions between populations and environment and exploitation impact on target-populations.

Moderator: P. Lorance

[14] Petitgas et al. Population responses to environmental forcing: approaches to model and monitor habitat characteristics

[15] Muths et al. Structure des stocks d'espadon (Xiphias gladius) dans le sud-ouest de l'océan Indien
[16] Bru et al. Daily and seasonal estimates of the recruitment and biomass of glass eels runs (Anguilla anguilla) and exploitation rates in the Adour open estuary (southwestern France)

[17] Bourjea et al. Analyse par spline linéaire des séries longues de comptage de traces de tortues marines dans les îles Eparses françaises

Poster session 1.2

[18] Riou et al. Suivi et compréhension du développement d'espèces phytoplanctoniques toxiques (Dynophysis sp. et Pseudonitzschia sp.) et des niveaux de contamination phycotoxinique des gisements de coquilles St Jacques en baie de Seine (France)

[19] Paroissin C., Prouzet P. Modélisations et simulations de scénarios de pêche de la civelle (Anguilla anguilla)

[20] Dang et al. Dynamique des populations de palourdes sur le bassin d'Arcachon - conséquence sur la gestion des populations exploitées

[21] Fifas et al. Comparaison des distributions spatiales de coquilles St-Jacques (Pecten maximus) et de crépidules (Crepidula fornicata) en baie de Saint-Brieuc. Résultats des campagnes d'évaluation directe, années 2003-2007

[22] Lelièvre et al. Identification and characterization of winter spawning grounds in the eastern English Channel and southern North Sea

[23] Persohn et al. Habitat preferences of selected demersal fish species in the Bay of Biscay and Celtic Sea, North-East Atlantic

[24] Drouineau et al. M. Développement et ajustement d'un modèle de dynamique des populations structuré en longueur et spatialisé appliqué au stock Nord de merlu (Merluccius merluccius)

[25] Muths D., Bourjea J. Connectivité entre les aires marines protéegées du sud ouest de l'océan Indien : étude de faisabilité

[26] Bourjea J. Interaction tortues marines-pêche hauturière dans le sud-ouest de l'océan Indien : projet SWIOFP

[27] Pawlowski L., Lorance P. Effect of discards on roundnose grenadier stock assessment in the Northeast Atlantic

Session 1.3. Space-time dynamics of assemblages and exploitation impact on non-target populations and communities. Moderator: V. Trenkel

[28] Fifas et al. Evaluation des rejets de langoustines (Nephrops norvegicus) occasionnés par le chalutage en golfe de Gascogne

[29] Trenkel et al. Overview of recent progress in fisheries acoustics made by Ifremer with examples from the Bay of Biscay

[30] Brind'Amour A., Lobry J. Assessment of the ecological status of coastal areas and estuaries in France, using multiple fishbased indicators: a comparative analysis on the Vilaine estuary

[31] Reecht et al. Defining functional groups in fish communities: usefulness of ecomorphology

[32] Benoît H.P., Swain, D.P. Changes in species composition of fish and macroinvertebrate communities in the southern Gulf of St. Lawrence: Impacts of environmental change and direct and indirect harvesting effects 
[33] Frank K. Structure and stability in exploited marine ecosystems: comparative dynamics

[34] Preuss et al. Etude de la variabilité spatio-temporelle de l'assemblage ichtyologique pour la compréhension de l'effet des changements de statuts de protection des AMP

[35] Claudet J., Pelletier D. Marine reserve local and regional effects: how fish assemblages respond to protection and importance of reserve design

Poster session 1.3

[36] Pelletier et al. High definition video systems for monitoring biodiversity in MPA

[37] Scalabrin C., Marfia C. How much fish is hidden in surface and bottom acoustic blind zones?

[38] Massé et al. From acoustic fisheries surveys to ecosystem monitoring surveys: the "Pelgas" series in the Bay of Biscay

[39] Choqueuse et al. Etude expérimentale du fonctionnement d'un récif artificiel à l'aide d'une station fixe acoustique autonome

[40] Lobry et al. Les ressources bentho-démersales côtières du golfe de Gascogne : comparaison à l'échelle d'un quart de siècle

[41] Warembourg et al. Contribution of image analysis to ecosystem approach to fisheries: the study of ichthyoplanktonic and zooplanktonic assemblages

[42] Laurans et al. Le projet Recopesca : un outil novateur de mesure de l'effort de pêche et des paramètres environnementaux. Illustration des résultats obtenus sur la pêcherie langoustinière de la grande vasière

\section{Theme 2. Economic viability of the fish chain: research and applications}

Session 2.1. Fish chain analysis and identification of constraints to its viability.

Moderator: P. Marchal

[43] Daurès et al. Fishing fleet typology, economic dependence, and species landing profiles of the French fleets in the Bay of Biscay, 2000-2006

[44] Rochet et al. Viabilité économique des flottilles de pêche et état de l'écosystème : vers une évaluation conjointe. Une application au golfe de Gascogne

[45] Reynal L., Guyader O. Allocation de l'effort de pêche entre écosystèmes récifaux et pélagiques dans les petites Antilles françaises

Poster session 2.1

[46] Daurès F. et al. Le poids économique des pêches côtières en France

[47] Marchal et al. Catch-quota balancing in mixed-fisheries: a bioeconomic modelling approach applied to the New Zealand hoki (Macruronus novaezelandiae) fishery

[48] Thébaud et al. Fishing the food web: a bio-economic analysis of changes and drivers of change in fisheries of the Bay of Biscay

[49] Leblond et al. A picture of French fleets fishing effort over the period 2000-2006 combining logbooks, auctions sales, VMS and calendar of activity data

[50] Daurès et al. Les flottilles et les revenus à la pêche dans la bande côtière bretonne
Session 2.2. Change scenarios for fisheries under ecological, economic and institutional stress. Moderator: O. Thébaut

[51] Martinet et al. Selecting viable recovery paths towards sustainable fisheries

[52] Macher C., Guyader O. Estimating the social cost of discarding: the case of the Nephrops trawl fishery's discards in the Bay of Biscay

[53] Marchal et al. A comparative review of the fisheries resources management systems in New Zealand and in the European Union

[54] Hamon et al. A retrospective analysis of the effects of adopting individual transferable quotas in the Tasmanian red rock lobster, Jasus edwardsii, fishery

[55] Vermard et al. Identifying fishing trip behavioral mode and fishing effort using Bayesian hidden Markov models

Poster session 2.2

[56] Mahévas et al. A simulation designs approach to assess the robustness of alternative management measures to fishermen behaviour : an application to the Bay of Biscay anchovy fishery

[57] Drouot et al. Analyse bio-économique de scénarios d'aménagement de la pêcherie de bar (Dicentrarchus labrax)

[58] Lehuta et al. Setting up the bio-economic simulation model ISISFish for the Bay of Biscay pelagic fishery

Session 2.3. Innovative techniques to reduce ecological impact of fishing and add value to products. Moderator: P. Berthou

[59] Macher C., Talidec C. From trawl to pots: a bio-economic analysis of gear change

[60] Morandeau et al. Evaluation de la faisabilité technicoéconomique de la pêche alternative du thon germon à la ligne de traîne automatique

[61] Vincent B. Synthèse des travaux effectués dans le domaine de l'optimisation des engins de pêche

[62] Debuquet et al. Comment concilier fraîcheur et qualité sanitaire dans la filière pêche : le cas d'Anisakis

[63] Morizur et al. Captures accidentelles de cétacés dans le chalutage pélagique en bouf et mitigation acoustique

Poster session 2.3

[64] Verrez-Bagnis et al. Traçabilité moléculaire des espèces de poissons marins au travers de trois projets

[65] Vauchel et al. Evaluation of reactive extrusion process from alginate extraction from Laminaria digitata

[66] Morandeau F., Larna P. Tests of square mesh side escape panels to decrease by-catch in Nehrops fisheries

[67] Larnaud et al. La grille à langoustines : une des solutions pour diminuer les rejets, fiable et extrapolable aux différentes pêcheries

[68] Morandeau G., Morandeau F. Essais de casiers à langoustines dans la fosse de Capbreton - Projet ITIS-SQUAL (sélectivité qualité des prises et techniques alternatives)

[69] Sacchi et al. Les nasses à poissons : alternative ou simple diversification

[70] Priour D. Variation in trawl cod-end selectivity due to the mechanical property of the catch and the netting

[71] Bergé et al. The French network SEApro: a solution to a better fish wastes management?

[72] Larnaud et al. Tests de dispositifs d'échappement de dauphins dans les chaluts pélagiques

[73] Meillat M., Morandeau F. Limitation des prises accessoires dans les pêcheries crevettières 
Theme 3. The ecosystem approach outputs: diagnoses on the health of ecosystems in fluctuating environments

Session 3.1. Multi-parameter databases. Accounting for multiple natural and human-induces stresses. Moderator: P. Berthou

[74] Badts V., Mahévas S. Les avancées de la démarche qualité du SIH : méthodes et exemples concrets

[75] Kostylev V.E. Habitat template approach to seabed mapping for ecosystem based management

[76] Trenkel V., Rochet M.J. Utilisation d'indicateurs pour évaluer l'état des communautés marines exploitées : le fil rouge

[77] Woillez et al. Monitoring fish population and environmental indicators for assessing the pelagic ecosystem in the Bay of Biscay

[78] Vaz et al. Modelling fish community habitat in the eastern English Channel: tentative prediction of habitat distribution change under different climatic variation scenarios

[79] Kraus et al. A model-based evaluation of Marine Protected Areas - the example of Eastern Baltic cod (Gadus morhua callarias)

Poster session 3.1

[80] Michel et al. Evolution of upper layer temperature in the Bay of Biscay during the last 40 years

[81] Caill-Milly et al. Identification et appréciation des usages dans les zones humides du bas Adour maritime afin de déceler les impacts des activités anthropiques sur l'habitat de l'anguille européenne (Anguilla anguilla)

[82] Delavenne et al. Comparative study of conservation planning strategies: a case study in the Eastern English Channel using MARXAN and ZONATION softwares
[83] Prouzet et al. Un réseau de connaissances sur l'anguille européenne (Anguilla anguilla) au sein de l'Espace Atlantique : le projet Indicang

[84] Amilhat et al. Estimation of the population size, exploitation rate and escapement of silver eels sub-stock in a Mediterranean lagoon: Bages-Sigean, France

Session 3.2. Development of cartographic visualization tools and spatial indicators dashboards. Moderator: A. Carpentier

[85] Lorance et al. Assessment of impacts from human activities on ecosystem components in the Bay of Biscay in the early 1990s

[86] Blanchard F., Thébaud O. Changement global, dynamique de la biodiversité marine exploitée et viabilité des pêcheries (CHALOUPE)

[87] Pelletier et al. withdrawn

[88] Martin et al. The Channel habitat atlas for marine resource management (CHARM): an aid for planning and decision-making in an area under strong anthropogenic pressure

[89] Gilbert M. Initiative de recherche écosystémique (IRÉ) dans l'estuaire du Saint-Laurent : contexte et application du concept d'approche écosystémique

Poster session 3.3

[90] Carpentier et al. Défi Manche

[91] Petitgas et al. Overview of the EU project FISBOAT

[92] Rocklin et al. Les réserves marines comme outil de gestion des pêches : la fermeture partielle de la pêche plaisancière profite à la pêche artisanale 